\title{
SINERGI BIROKRASI, SWASTA DAN MASYARAKAT DALAM PROSES FORMULASI KEBIJAKAN PERENCANAAN PADA BAPPEDA DAN PENANAMAN MODAL KABUPATEN BUTON
}

\author{
ANWAR SADAT \\ Fakultas Ilmu Sosial dan Ilmu Politik Universitas Muhammadiyah Buton \\ Email : nua nsa@yahoo.com \\ DIRMANSYAH \\ Fakultas Ekonomi dan Bisnis Universitas Mercu Buana Jakarta \\ Email : dirmansyahkenzie@ymail.com
}

\begin{abstract}
ABSTRAK
Dalam konteks otonomi daerah, harapannya menjadi sarana terjadinya sinergi birokrasi, Swasta dan Masyarakat dalam Proses Formulasi Kebijakan Perencanaan pada Bappeda dan Penanaman Modal Kabupaten Buton. Tujuan penelitian ini adalah mengkaji proses formulasi kebijakan perencanaan pada Badan Perencanaan Pembangunan Daerah Kabupaten Buton dan peran para stakeholders dalam proses formulasi kebijakan perencanaan pada Bappeda dan Penanaman Modal Kabupaten Buton.

Penelitian ini menjelaskan bahwa Perencanaan menjadi katalisator pembangunan daerah yang didukung oleh masyarakat setempat, masyarakat memahami tentang kebijakan pemerintah dan dapat memperhitungkan kemampuannya dalam mendukung pembangunan daerah. Pola penyelenggaraan pemerintahan yang baik dalam era otonomi daerah tujuan mempromosikan good governance pada tingkat pemerintah daerah, melalui partisipasi publik dalam proses pengambilan kebijakan. Sampai sekarang belum terungkap bagaimana peran para stakeholders dalam proses perumusan kebijakan publik di Kabupaten Buton, disamping dapat berpengaruh terhadap sinergi para stakeholders dalam proses perumusan kebijakan pada Bappeda dan Penanaman Modal di kabupaten Buton.
\end{abstract}

Keywords : Birokrasi, Kebijakan, Bappeda, Buton 


\section{A. Latar Belakang}

Seiring dengan dinamika dan kompleksnya tuntutan pelayanan kepada masyarakat, pemerintah tidak lagi dapat mengklaim dirinya sebagai satu-satunya sumber kekuasaan yang absah. Paradigma pemerintah sebagai $a$ governing process ditandai oleh praktek pemerintahan yang berdasarkan pada konsensus-konsensus etis antara pemimpin dengan masyarakat. Pemerintahan dijalankan berdasarkan kesepakatan-kesepakatan yang terbentuk melalui diskusi dan diskursus yang berlangsung dalam ruang publik. Dalam konteks ini, penyelenggaraan pemerintahan, pembangunan dan pelayanan publik tidak semata-mata didasarkan pada pemerintah, tetapi dituntut adanya keterlibatan seluruh elemen, baik intern birokrasi, maupun masyarakat dan pihak swasta. Pemikiran tersebut hanya akan terwujud manakala pemerintah didekatkan dengan yang diperintah, atau dengan kata lain terjadi desentralisasi dan otonomi daerah.

Dampak reformasi yang terjadi di Indonesia, ditinjau dari segi politik dan ketatanegaraan, adalah terjadinya pergeseran paradigma dan sistem pemerintahan yang bercorak monolitik sentralistik di pemerintah pusat ke arah sistem pemerintahan yang desentralistik (lokal democrasi) di pemerintah daerah (Utomo, 2007:21). Pemerintahan semacam ini memberikan keleluasaan kepada Daerah dalam wujud "Otonomi Daerah" yang luas dan bertanggung jawab, untuk mengatur dan mengurus kepentingan masyarakat setempat, berdasarkan prinsip-prinsip demokrasi, peran serta, prakarsa dan aspirasi masyarakat sendiri atas dasar pemerataan dan keadilan, serta sesuai dengan kondisi, potensi dan keragaman daerah.

Otonomi Daerah sebagai wujud pelaksanaan asas desentralisasi dalam penyelenggaraan pemerintahan yang digulirkan oleh Pemerintah sebagai jawaban atas tuntutan masyarakat, pada hakekatnya merupakan penerapan konsep teori areal division of power yang membagi kekuasaan negara secara vertikal. Kondisi ini membawa implikasi terhadap perubahan paradigma pembangunan yang dewasa ini diwarnai dengan isyarat globalisasi. Konsekuensinya, berbagai kebijakan publik dalam kegiatan pemerintahan, pembangunan dan pelayanan publik menjadi bagian dari dinamika yang harus direspons dalam kerangka proses demokratisasi, pemberdayaan masyarakat dan kemandirian lokal.

Kebijakan desentralisasi yang tertuang dalam UU Nomor 32 Tahun 2004 merupakan strategi baru yang membawa harapan dalam memasuki era reformasi, globalisasi serta perdagangan bebas. Harapan tersebut muncul oleh karena kebijakan ini dipandang sebagai jalan baru untuk menciptakan suatu tatanan yang lebih baik dalam sebuah skema good governance dengan segala prinsip dasarnya. Melalui pemerintahan yang desentralistik, akan terbuka wadah demokrasi bagi masyarakat lokal untuk berperan serta dalam menentukan nasibnya, serta berorientasi kepada kepentingan rakyat melalui pemerintahan daerah yang terpercaya, terbuka dan jujur serta bersikap tidak mengelak tanggung jawab (passing the buck) sebagai prasyarat terwujudnya 
pemerintahan yang akuntabel dan mampu memenuhi asas-asas kepatutan dalam pemerintahan (good governance).

Konsep good governance sendiri dalam beberapa tahun belakangan ini banyak dibicarakan dalam berbagai konteks dan menjadi issue yang paling mengemuka dalam pengelolaan pemerintahan dan pelayanan kepada publik. Tuntutan ini sebagai akibat dari pola-pola lama penyelenggaraan pemerintahan dirasakan tidak sesuai lagi bagi tatanan masyarakat yang telah berubah atau dengan kata lain semakin tidak efektifnya pemerintahan disamping semakin berkembangnya kualitas demokrasi, hak asasi manusia dan partisipasi publik dalam pengambilan kebijakan. Jadi ada tekanan untuk mendefinisikan ulang terhadap peran-peran pemerintahan dalam hubungannya dengan masyarakat dan sektor swasta.

Sebagai suatu alternatif pengelolaan pemerintahan, konsep good governance berakar pada suatu gagasan adanya saling ketergantungan (interdependence) dan interaksi dari bermacam-macam aktor kelembagaan di semua level/tingkat dalam negara, yakni pemerintah, swasta dan civil society dalam menjalankan fungsinya masing-masing. Sedangkan society berperan positif dalam interaksi sosial, ekonomi dan politik termasuk mengajak kelompok-kelompok dalam masyarakat untuk berpartisipasi dalam aktivitas ekonomi, sosial dan politik. Pada tataran ini, perlu adanya keseimbangan hubungan yang sehat antara aktor (domain), sehingga tidak boleh ada aktor kelembagaan di dalam good governance yang mempunyai kontrol yang absolut.

Ketika ada keinginan untuk melakukan re-definisi terhadap pola penyelenggaraan pemerintahan yang terjadi selama ini dan pada saat yang bersamaan pula kebijakan otonomi daerah digulirkan, pertanyaan yang segera muncul adalah apakah dengan demikian, pembangunan akan lebih dekat dengan masyarakat atau dengan kata lain pemerintah, melalui kebijakankebijakannya akan lebih berpihak kepada masyarakat dan dunia usaha, disamping seberapa besar akses yang dimiliki oleh para stakeholder untuk turut serta mengambil bagian dalam proses pemerintahan dan pembangunan?. Untuk menjawab pertanyaan tersebut, perencanaan sebagai bentuk partisipasi masyarakat dan dunia usaha menjadi salah satu syarat untuk mengembangkan pengelolaan pemerintahan yang baik (good governance), sebab perencanaan merupakan proses awal, sebelum langkah-langkah yang bakal mempengaruhi kehidupan masyarakat berjalan. Asumsi ini didasarkan pada pemikiran bahwa jika dalam perencanaan telah dengan sengaja mengabaikan suara rakyat, maka dengan sendirinya langkah-langkah yang akan diciptakan bisa mengancam kehidupan masyarakat. Sebaliknya, jika perencanaan disusun dengan melibatkan masyarakat, maka besar kemungkinan akan mendekatkan kegiatan pemerintahan dan pembangunan dengan kebutuhan masyarakat. Tuntutan penyelenggaraan pemerintahan yang solid dan bertanggung jawab serta efisien dan 
efektif dengan senantiasa menjaga kesinergisan interaksi yang konstruktif diantara komponen (pemerintah, swasta dan civil society) dalam rangka melaksanakan berbagai tantangan otonomi daerah tidak dapat dielakan lagi.

Dalam konteks otonomi daerah,

Badan Perencanaan Pembangunan Daerah merupakan institusi teknis Pemerintah Daerah yang secara langsung bertanggung jawab dalam rangka perencanaan pembangunan $\mathrm{di}$ Daerah. Berdasarkan Perda Nomor 14 Tahun 2011 Tentang Susunan Organisasi dan Tata Kerja Lembaga Teknis Daerah Kabupaten Buton, Bappeda dan Penanaman Modal berkedudukan sebagai unsur penunjang Pemerintah Daerah yang mempunyai tugas pokok membantu Bupati dalam penyelenggaraan Pemerintahan Daerah dibidang Perencanaan Pembangunan Daerah. Untuk melaksanakan tugas tersebut, maka Bappeda dan Penanaman Modal mempunyai fungsi dalam perumusan kebijakan pembangunan di bidang Perencanaan Pembangunan Daerah, memberikan layanan penunjang penyelenggaraan Pemerintahan Daerah di bidang Perencanaan Pembangunan Daerah, dan melaksanakan tugas lain yang diberikan oleh Bupati dalam bidang Perencanaan Pembangunan di Daerah. Perencanaan sebagai suatu proses pembuatan kebijakan hendaknya melibatkan para stakeholder, sebagaimana dikemukakan oleh Don K. Price (Wahab ; 2001, 16) bahwa proses pembuatan kebijakan yang bertanggung jawab ialah proses yang melibatkan interaksi antara kelompok-kelompok ilmuwan, pemimpin-pemimpin organisasi professional, para administrator dan para politisi.

Berdasarkan visi dan misi yang diemban Bappeda dan Penanaman Modal Kabupaten Buton dalam melaksanakan tugas pokoknya, maka disadari bahwa lingkungan eksternal sangat berpengaruh, mengingat setiap aspek kegiatan yang dilakukan oleh Bappeda dan Penanaman Modal diperlukan peran serta dari pihak-pihak lain sehingga keterlibatan tersebut diharapkan dapat mendorong keberhasilan pelaksanaan tugas Bappeda dan Penanaman Modal, khususnya dalam merumuskan kebijakan-kebijakan dibidang perencanaan pembangunan yang pada akhirnya kebijakan tersebut akan menjadi pedoman bagi para stakeholders pengelola pembangunan daerah. Pada tataran ini, kondisi yang ingin diwujudkan adalah perencanaan pembangunan daerah yang partisipatif, yang disusun berdasarkan hasil dari aspirasi yang berkembang, baik dari masyarakat, pemerintah maupun pihak swasta. Meskipun dalam paradigma Good Governance dituntut adanya sinergi antar komponen (stakeholders) didalamnya atau dengan kata lain tidak ada institusi yang dominan, akan tetapi dalam kenyataan saat ini, peran pemerintah cenderung dominan apabila dibandingkan dengan pihak (domain) lainnya, terlebih pada saat pelaksanaan otonomi daerah, dimana kewenangan Pemerintah Daerah sangat besar, melalui fungsi pengaturan yang memfasilitasi sektor swasta dan masyarakat serta fungsi administratif dalam penyelenggaraan pemerintahan. 
Pertanyaan yang kemudian muncul dalam penelitian ini adalah Bagaimana proses perumusan kebijakan perencanaan pada Bappeda dan Penanaman Modal Kabupaten Buton?, Bagaimana peran para stakeholders (pemerintah, swasta dan masyarakat) dalam proses formulasi kebijakan perencanaan pada Bappeda dan Penanaman Modal Kabupaten Buton?

\section{B. METODE PENELITIAN}

Penelitian ini menggunakan kaidah dalam metode kualitatif, penelitian dilakukan dengan melakukan serangkaian wawancara mendalam kepada sejumlah Informan yang terlibat langsung pada seluruh tahapan proses kebijakan, sebagai pembanding maka wawancara juga dilakukan kepada sejumlah informan yang mana posisinya sebagai pengguna/ masyarakat yang menjadi sasaran kebijakan.

Untuk memahami proses yang dijalani dalam penelitian ini, dapat diamati pada gambar berikut ini

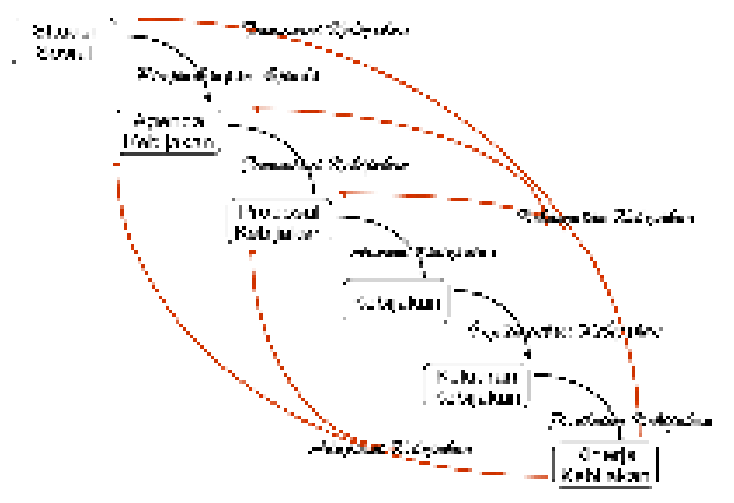

Gambar 1.

Indikator Proses Fomulasi Kebijakan.

\section{HASIL PENELITIAN DAN PEMBAHASAN}

\section{Kinerja Pelayanan Bappeda dan PM Kab. Buton}

Capaian kinerja dari pelaksanaan program dan/atau kegiatan yang terdapat dalam Renstra-Bappeda-PM Kabupaten Buton selama kurun waktu 2007-2011 dapat dilihat dari beberapa aspek :

a. Data base

Selama kurun waktu 2007-2011, data base yang tersedia di Bappeda dan PM Kabupaten Buton terutama berasal dari Badan Pusat Statistik (BPS) Kabupaten Buton. Beberapa data base yang telah dihasilkan seperti buku Kabupaten Buton Dalam Angka, Kecamatan Dalam Angka, Indeks Pembangunan Manusia (IPM) Kabupaten Buton, PDRB Kabupaten Buton, buku Indikator Kesejahteraan Rakyat (Inkesra), buku Pola Konsumsi Kabupaten Buton, buku profil daerah Kabupaten Buton. Namun, seiring dengan dinamika pembangunan daerah di Kabupaten Buton, maka ketersediaan data base saat ini dirasakan masing kurang memadai lagi, masih bayak data base yang harus disiapkan dalam mendukung penyusunan dokumen perencanaan.

b. Dokumen hasil kajian pembangunan. Guna mendukung perencanaan pembangunan di Kabupaten Buton, baik saat ini maupun di masa mendatang, selama kurun waktu 2007-2011, telah dilakukan beberapa studi atau kajian pembangunan, seperti penyusunan dokumen 
Rencana Pengembangan Permukiman dan Perumahan Daerah (RP4D), penyusunan desain mina politan, penyusunan indikator ekonomi, penyusunan perencanaan pengembangan wilayah strategis dan cepat tumbuh. Di masa-masa mendatang, ketersediaan dokumen hasil kajian ini akan terus ditingkatkan seiring dengan dinamika dan kebutuhan pembangunan Kabupaten Buton.

c. Dokumen perencanaan pembangunan.

Sebagaimana dinyatakan dalam Undang-Undang No. 25 Tahun 2004 tentang Sistem Perencanaan Pembangunan Nasional dan UndangUndang No. 32 Tahun 2004 tentang Pemerintahan Daerah, Bappeda diberikan kewenangan dalam penyusunan dokumen perencanaan pembangunan daerah. Selama kurun waktu 2007-2011, beberapa dokumen perencanaan pembangunan yang telah disusun di Kabupaten Buton antara lain adalah dokumen RP4D, Penetapan Rencana Pembangunan Jangka Panjang (RPJPD) Kab. Buton Tahun 20052025, Rencana Pembangunan Jangka Menengah Daerah (RPJMD) Kab. Buton Tahun 2007-2011, Rencana Strategis (Renstra) Bappeda Kab. Buton Tahun 2007-2011, Rencana Kerja Pemerintah Daerah (RKPD) Tahun 2008-2012, Kebijakan Umum Anggaran (KUA) dan Prioritas dan Plafon Anggaran Sementara (PPAS) APBD Tahun 2008-2011, penyusunan Laporan Keterangan Pertanggungjawaban (LKPJ) Kepala Daerah Tahun 2008-2012, penyusunan Laporan Keterangan Pertanggungjawaban (LKPJ) Kepala Daerah 5 tahun selama kurun waktu 2007-2011, penyusunan buku memori bupati buton periode 20072011, serta penyusunan Laporan Akuntabilitas Kinerja Instansi Pemerintah (LAKIP) Kabupaten Buton selama kurun waktu 20082012.

d. Sumber daya manusia perencana. Dalam rangka peningkatan kualitas Sumber Daya Manusia (SDM) perencana, selama kurun waktu 2007-2011, telah dilaksanakan pelatihan perencanaan partisipatif bagi perangkat kecamatan, pelatihan aparat perencana bagi aparatur perencana SKPD se Kabupaten Buton. Selain itu, untuk meningkatkan kualitas SDM aparatur Bappeda dan PM, juga telah diikutsertakan dalam beberapa Pendidikan dan Pelatihan (Diklat) maupun Bimbingan Teknis (Bimtek).

e. Kerjasama Pembangunan dengan Pihak Luar

Selama kurun waktu 2007-2011, Bappeda dan PM Kabupaten Buton telah melakukan beberapa program kerjasama pembangunan dengan lembaga lain antara lain penunjangan TMMD, pendampingan dan penunjang target MDGs Kab. Buton, penunjangan Bantuan Stimulan Pembangunan Perumahan Swadaya (BSP2S) dan peningkatan kualitas perumahan bekerja sama dengan Kementerian Perumahan Rakyat, perencanaan pembangunan kawasan terpadu bekerja sama dengan Kementerian Pembangunan Daerah Tertinggal, Program Penanggulangan 
Kemiskinan Perkotaan (P2KP), program MCRMP Kab. Buton, Program Access maupun Program SCBD yang dilakukan dengan bekerjasama dengan Asian Developmen Bank (ADB).

\section{Tantangan Dan Peluang Pengembangan Pelayanan Bappeda Dan PM Kabupaten Buton}

Berdasarkan capaian kinerja dari Badan Perencanaan Pembangunan Daerah dan Penanaman Modal (Bappeda dan PM) Kabupaten Buton selama tahun 20072011, maka bersamaan dengan hal tersebut beberapa yang dihadapi oleh Bappeda dan PM Kabupaten Buton dalam memperkuat ekisistensinya sebagai Lembaga Teknis Daerah yang membantu Bupati Buton dalam perencanaan dan perumusan kebijakan perencanaan dan penanaman modal daerah adalah sebagai berikut :

a. Sumber Daya Manusia Perencana

Sumber Daya Manusia (SDM) perencana yang berkualitas merupakan pelopor dan penentu arah pembangunan daerah. Dari segi kuantitas, SDM aparatur Bappeda dan PM sudah cukup memadai untuk melaksanakan tugas-tugas perencanaan secara prosedural, namun dari segi kualitas, SDM yang memiliki kompetensi untuk melakukan analisis perencanaan, penganggaran, pelaksanaan, pelaporan secara baik dan akuntabel masih kurang. Oleh karena itu, ke depan upaya peningkatan kualitas SDM aparatur perencana menjadi sesuatu yang penting dalam upaya mewujudkan rencana pembangunan yang berkualitas.

b. Data Base

Data merupakan informasi awal yang sangat dibutuhkan dalam melakukan perencanaan maupun mengukur keberhasilan pembangunan yang telah dilaksanakan. Data sekaligus merupakan titik awal (starting point) untuk menentukan kebijakan yang akan diambil berkaitan dengan program dan/atau kegiatan yang sedang dan akan dilaksanakan. Dalam beberapa tahun terakhir, Kabupaten Buton telah mempunyai data base yang relatif baik, akan tetapi seiring dengan dinamika dalam perencanaan pembangunan dan penyusunan dokumen perencanaan, maka dirasakan ada beberapa permasalahan dalam penyediaan data base saat ini, yaitu Lemahnya data base capaian pelaksanaan program pembangunan dari SKPD.

c. Penyediaan Dokumen Perencanaan Dalam beberapa tahun terakhir, Bappeda dan PM Kabupaten Buton telah melakukan penyusunan beberapa dokumen pembangunan, mulai dari dokumen perencanaan tahunan, lima tahunan maupun berbagai kajian pendukung dalam penyusunan dokumen perencanaan pembangunan. Akan tetapi, permasalahan yang muncul dalam penyediaan dokumen perencanaan dan keuangan, antara lain kurang optimalnya dukungan dari SKPD dalam memberikan informasi yang berkaitan dengan kinerja 
program/kegiatan pembangunan yang telah dilakukan; masih lemahnya koordinasi perencanaan dengan unit kerja; belum adanya dokumen RTRW Kab. Buton; masih lemahnya cakupan dan muatan isi dari hasil monitoring dan evalusi program pembangunan sehingga kurang memberikan informasi sebagai umpan balik dalam penyusunan perencanaan program yang bersangkutan serta belum memadainya ketersediaan hasil kajian atau dokumen perencanaan pengembangan wilayah.

d. Sarana dan Prasarana Pendukung Sarana dan prasarana pendukung sangat penting peranannya dalam menunjang kelancaran pelaksanaan Tugas Pokok dan Fungsi unit kerja. Ruang kerja kantor yang ditempati oleh Bappeda dan PM Kabupaten Buton apabila dilihat dari kondisi dan luas ruang kerja masing-masing bidang belum nyaman dan kurang mendukung. Terlebih lagi, belum adanya ruang pertemuan/aula sebagai tempat melaksanakan koordinasi dengan SKPD. Selain itu pula sarana dan prasarana yang ada sudah banyak dalam keadaan kurang baik/rusak, sehingga tidak dapat lagi digunakan untuk menunjang kelancaran tugas. Oleh karena itu, ke depan diharapkan tersedia ruang kerja tambahan dan ruang pertemuan serta sarana prasarana yang lebih baik.

\section{Kebijakan Bappeda dan Penanaman Modal}

Badan Perencanaan Pembangunan Daerah dan Penanaman Modal
Kabupaten Buton, menguraikan tentang prediksi berbagai permasalahan yang akan dihadapi pada tahun 2013 dan kebijakan-kebijakan yang akan dilakukan guna memecahkan permasalahan yang dihadapi.

1) Permasalahan Yang Dihadapi

Dari Pelaksanaan Program Kegiatan perencanaan yang dilakukan oleh Badan Perencanaan Pembangunan Daerah dan Penanaman Modal Kabupaten Buton, selama ini telah mewujudkan adanya capaian hasilhasil pembangunan yang cukup mengembirakan, walaupun pada beberapa hal disadari masih terdapat berbagai masalah pokok yang belum terselesaikan, dalam program kegiatan pembangunan dan perencanaan yang terdahulu, sehingga masih perlu penanganan dan diselesaikan pada tahun-tahun mendatang, guna menghasilkan capaian yang lebih optimal dalam kerangka mewujudkan visi dan misi Bappeda dan Penanaman Modal Kabupaten Buton. Secara umum permasalahan utama yang dihadapi oleh Bappeda dan Penanaman Modal pada tahun 2012 adalah :

a) Keterbatasan data dan informasi yang diperlukan bagi perencanaan pembangunan dan penanaman modal.

b) Belum optimalnya kemampuan sumber daya manusia dalam perencanaan pembangunan daerah serta ketersediaan sarana prasarana yang belum memadai.

c) Belum optimalnya koordinasi dalam perencanaan pembangunan yang menyebabkan rendahnya 
keterpaduan dalam fungsi perencanaan, monitoring dan evaluasi pembangunan.

Belum optimalnya pelaksanaan monitoring dan evaluasi program-program pembangunan yang dikaitkan dengan dokumendokumen perencanaan.

2) Kebijakan

Pembangunan

Perencanaan

Kebijakan Badan Perencanaan Pembangunan Daerah dan Penanaman Modal tahun 2013 sesuai dengan tugas pokok dan fungsi serta kewenangan yang dimiliki, dengan mempertimbangkan kondisi dan kemampuan keuangan daerah, maka kebijakan yang diambil adalah diprioritaskan pada pengimplementasian UU No. 25 tahun 2004 tentang sistem perencanaan pembangunan nasional, agar Perencanaan Pembangunan yang dilaksanakan dapat Sinergis, Akurat dan Akuntabel sesuai dengan kebutuhan masyarakat dan daerah, serta sistem Koordinasi dapat berjalan sesuai dengan peraturan yang berlaku dan pelaksanaan pengendalian serta evaluasi sesuai dengan harapan. Disamping itu kebijakan- kebijakan yang diambil tersebut diharapkan dapat memecahkan persoalanpersoalan yang dihadapi tersebut. Kebijakan Umum Pembangunan pada dasarnya merupakan bagian dari upaya pencapaian visi, misi, tujuan dan sasaran yang telah ditetapkan dalam Rencana Strategis (Renstra) Bappeda dan Penanaman Modal tahun 2013-2017. Kebijakan
Pembangunan tahun 2013, merupakan program jangka pendek sebagai tingkat pencapaian kinerja pelayanan yang direncanakan dalam satu tahun anggaran, dan merupakan implementasi pelaksanaan dari program pembangunan jangka menengah dan jangka panjang daerah. Dalam penyelenggaraan perencanaan Kabupaten

Buton untuk mencapai sasaran pembangunan Bappeda dan Penanaman Modal menetapkan 5 (Lima) kebijakan prioritas tahun 2013-2017 sebagai berikut :

1. Peningkatan kapasitas kelembagaan perencanaan dengan pemenuhan kebutuhan kuantitas dan kualitas SDM serta perangkat pendukungnya termasuk pembaharuan dan analisis data perencanaan dan penyediaan sistem informasi perencanaan pembangunan.

2. Peningkatan kualitas koordinasi perencanaan, monitoring dan evaluasi melalui kerjasama perencanaan pembangunan antar lembaga dan antar daerah dengan memanfaatkan dokumen perencanaan sebagai pedoman dan acuan.

3. Peningkatan kualitas pelaksanaan perencanaan pembangunan daerah melalui pelaksanaan mekanisme perencanaan pembangunan yang tepat waktu dengan efisien, efektif dan partisipatif dalam mencapai konsistensi pelaksanaan pembangunan antara lain dengan penyusunan peraturan daerah tentang mekanisme perencanaan pembangunan daerah serta 
meningkatkan partisipasi masyarakat dalam perencanaan pembangunan daerah termasuk dengan peningkatan pelibatan LSM dan Perguruan Tinggi sebagai mitra.

4. Mengembangkan

mekanisme perencanaan pembangunan daerah sesuai UU No. 25 Tahun 2004 melalui penyusunan peraturan daerah tentang mekanisme perencanaan pembangunan daerah termasuk kelembagaan perencanaan daerah.

5. Mendorong perbaikan iklim investasi melalui pemberian pencerahan terhadap setiap rencana kebijakan pada percepatan pengembangan sektor riil dan pemberdayaan usaha mikro, kecil dan menengah pada SKPD teknis lingkup pemerintah kabupaten.

\section{Sinergi Birokrasi, Swasta Dan Masyarakat Dalam Proses Formulasi Kebijakan Perencanaan Pada Bappeda Dan Penanaman Modal Kabupaten Buton}

Didalam bab ini peneliti akan menganalisis data hasil penelitian di lapangan, data yang diperoleh merupakan hasil observasi, wawancara dengan untuk memperoleh informasi dan data yang relevan dari informan kunci (key informan), laporan serta buku-buku yang mendukung penelitian ini. Semua data akan diolah dengan metode kualitatif deskriptif. Sinergi Birokrasi, Swasta Dan Masyarakat Dalam Proses Formulasi Kebijakan Perencanaan Pada Bappeda Dan Penanaman Modal Kabupaten Buton berdasarkan hasil wawancara penulis dengan Kepala Bappeda dan PM Kabupaten Buton Bapak Muh. Ilyas Abibu, SE.,MDM beliau menyatakan bahwa:

“...Ketika pemerintah mengontrakkan beberapa kegiatan kepada sektor swasta, mereka tetap membuat keputusan kebijakan dan memberikan pembiayaan. Dan untuk dapat melakukan itu dengan baik, maka haruslah pemerintahan yang berkualitas, Birokrasi dianggap telah menjadi sumber inefisiensi. Oleh karena itu keterlibatan pemerintah dalam berbagai kegiatan perlu dikurangi, dengan asumsi peran tersebut akan digantikan oleh aktor lain seperti asosiasi sukarela dan mekanisme pasar, munculnya governance bodies, yakni lembaga nonpemerintah yang diberi mandat dan kewenangan oleh pemerintah untuk mengambil kebijakan dalam bidang tertentu. Selama ini pemerintah memonopoli pengambilan kebijakan. Munculnya governance bodies yang anggotaanggotanya terdiri dari unsur pemerintah, swasta dan masyarakat, membuat persoalan publik tidak lagi dikatakan didominasi oleh pemerintah seperti selama ini terjadi". (Hasil wawancara tanggal 2 September 2013).

Demikian juga apa yang dikemukakan oleh Sekretaris Bappeda dan PM Kabupaten Buton Bapak Sunardin Dani, SE, dalam wawancara dengan penulis menyatakan:

“...Menguatnya Sinergi Birokrasi,Swasta dan masyarakat yang membuat proses kebijakan publik tidak lagi dapat didominasi oleh Bappeda dan PM saja. Pelibatan aktor-aktor di luar pemerintah dikarenakan tuntutan akan kualitas kebijakan yang semakin tinggi, dengan asumsi bahwa mereka 
memiliki informasi, pengalaman, dan tacit knowledge yang lebih baik daripada aktor-aktor yang selama ini memiliki otoritas yang sah".( Hasil wawancara tanggal 2 September 2013).

Selanjutnya dalam Proses Formulasi Kebijakan Perencanaan Pada Bappeda Dan Penanaman Modal Kabupaten Buton, dari hasil wawancara dengan Kasubag Penyusunan program, Merye ADH, SP menyatakan:

“...semakin banyaknya kebutuhan masyarakat yang tidak dapat dipenuhi oleh pemerintah. Kondisi ini membuat banyak kebutuhan masyarakat sebagai kolektivitas seperti barang-barang publik dan semi publik yang diselenggarakan oleh lembaga non pemerintah. Organisasi masyarakat sipil, asosiasi sukarela, dan lembaga-lembaga non pemerintah banyak bermunculan dengan aktivitas yang mengambil alih peran pemerintah".

(Hasil wawancara tanggal 2 September 2013).

Hal ini menuntut peningkatan peran dan kapasitas seluruh SKPD termasuk Bappeda dan PM yang diberi tugas dalam perencanaan pembangunan daerah untuk mengatasi permasalahan dan tantangan tersebut. Peran Bappeda dan PM sangat strategis karena perencanaan merupakan pijakan awal untuk menentukan arah pembangunan daerah dengan mengoptimalkan sumber daya dan melibatkan para pelaku pembangunan/stakeholder.

\section{Strategi dan Kebijakan Bappeda dan PM Kab. Buton}

Strategi adalah keseluruhan cara atau langkah dengan penghitungan yang pasti untuk mencapai tujuan atau mengatasi persoalan. Cara atau langkah dirumuskan lebih bersifat makro dibandingkan dengan "teknik" yang lebih sempit, dan merupakan rangkaian kebijakan. Sehingga strategi merupakan cara mencapai tujuan dan sasaran yang dijabarkan ke dalam kebijakankebijakan dan program-program.

Di dalam mewujudkan visi dan menjalankan misi serta mencapai tujuan dan sasaran seperti tersebut di atas, ditempuh dengan strategi pokok penyelenggaraan perencanaan pembangunan daerah, sebagai berikut : 


\section{Tabel 1}

Tujuan, Sasaran, Strategi dan Kebijakan Bappeda dan PM Kabupaten Buton

\begin{tabular}{|c|c|c|c|}
\hline \multicolumn{4}{|l|}{ Visi } \\
\hline \multicolumn{4}{|c|}{$\begin{array}{l}\text { Misi } 1 \text { : Mengembangkan kapasitas kelembagaan melalui peningkatan kualitas sumber daya } \\
\text { manusia dan perangkat pendukung perencanaan termasuk data dan sistim informasi } \\
\text { perencanaan pembangunan yang terbarukan serta ketersediaan sarana dan } \\
\text { prasarana }\end{array}$} \\
\hline Tujuan & Sasaran & Strategi & Kebijakan \\
\hline $\begin{array}{l}\text { Mewujudkan } \\
\text { sistem } \\
\text { kelembagaan yang } \\
\text { baik }\end{array}$ & $\begin{array}{l}\text { Meningkatnya } \\
\text { sarana } \\
\text { prasarana dan } \\
\text { fasilitasi } \\
\text { perencanaan } \\
\text { pembangunan } \\
\text { serta basis data } \\
\text { perencanaan } \\
\text { pembangunan } \\
\text { Meningkatnya } \\
\text { kualitas SDM } \\
\text { perencana } \\
\text { pembangunan }\end{array}$ & $\begin{array}{l}\text { Meningkatkan } \\
\text { kualitas fasilitasi } \\
\text { perencanaan } \\
\text { dengan } \\
\text { stakeholders }\end{array}$ & $\begin{array}{l}\text { Melaksanakan fasilitasi } \\
\text { pendidikan dan pelatihan } \\
\text { fungsional perencanaan } \\
\text { serta meningkatkan } \\
\text { orientasi dan memperluas } \\
\text { wawasan perencanaan } \\
\text { pembangunan }\end{array}$ \\
\hline
\end{tabular}

Misi 2 : Meningkatkan kualitas perencanaan pembangunan daerah dengan mampu melaksanakan mekanisme perencanaan pembangunan daerah yang tepat waktu, efisien dan efektif, yang tanggap terhadap perubahan dan partisipatif

\begin{tabular}{|c|c|c|c|}
\hline $\begin{array}{l}\text { Meningkatnya } \\
\text { kualitas } \\
\text { perencanaan yang } \\
\text { sesuai dengan } \\
\text { kondisi lokal }\end{array}$ & $\begin{array}{l}\text { Tersedianya } \\
\text { dokumen } \\
\text { perencanaan } \\
\text { pembangunan } \\
\text { daerah tahunan }\end{array}$ & $\begin{array}{l}\text { Meningkatkan } \\
\text { peran sebagai } \\
\text { fungsi manajemen } \\
\text { dalam bidang } \\
\text { perencanaan dan } \\
\text { bertanggungjawab } \\
\text { atas hasilnya } \\
\text { sebagai bagian dari } \\
\text { manajemen } \\
\text { pembangunan dan } \\
\text { mewujudkan } \\
\text { sinergitas } \\
\text { monitoring dan } \\
\text { evaluasi } \\
\text { pelaksanaan } \\
\text { pembangunan } \\
\text { daerah }\end{array}$ & $\begin{array}{l}\text { Mengembangkan jejaring } \\
\text { antar SKPD dan pelaku } \\
\text { pembangunan dalam } \\
\text { proses perencanaan } \\
\text { pembangunan dan proses } \\
\text { monitoring dan evaluasi } \\
\text { pelaksanaan } \\
\text { pembangunan }\end{array}$ \\
\hline
\end{tabular}

Misi 3 : Meningkatkan kualitas koordinasi perencanaan, monitoring dan evaluasi melalui kerjasama perencanaan pembangunan antar lembaga dan antar daerah

\begin{tabular}{|c|c|c|c|}
\hline $\begin{array}{l}\text { Meningkatkan } \\
\text { sistim koordinasi } \\
\text { yang terintegrasi } \\
\text { dalam proses } \\
\text { perencanaan, } \\
\text { pelaksanaan, } \\
\text { pengendalian } \\
\text { pembangunan }\end{array}$ & $\begin{array}{l}\text { Terjalinnya } \\
\text { komunikasi dan } \\
\text { koordinasi } \\
\text { perencanaan } \\
\text { pembangunan } \\
\text { seluruh } \\
\text { stakeholder }\end{array}$ & $\begin{array}{l}\text { Meningkatkan } \\
\text { komunikasi dan } \\
\text { koordinasi } \\
\text { perencanaan } \\
\text { pembanguann } \\
\text { seluruh stakeholder }\end{array}$ & $\begin{array}{l}\text { Mengefektifkan koordinasi } \\
\text { yang terintegrasi dalam } \\
\text { proses perencanaan, } \\
\text { pelaksanaan, } \\
\text { pengendalian } \\
\text { pembangunan pada semua } \\
\text { sektor dan stakeholder }\end{array}$ \\
\hline
\end{tabular}




\begin{tabular}{|c|c|c|c|}
\hline $\begin{array}{l}\text { : Terwuju } \\
\text { Respons } \\
\text { Masyaro }\end{array}$ & $\begin{array}{l}\text { Lembaga Pere } \\
\text { tisipatif Serta }\end{array}$ & $\begin{array}{l}\text { un Pembangune } \\
\text { udkan Iklim Inv }\end{array}$ & iis, \\
\hline $\begin{array}{ll}\text { si } 4 & \text { : Meningk } \\
& \text { ekonominy }\end{array}$ & lomamnum & & \\
\hline $\begin{array}{l}\text { Meningkatkan } \\
\text { produktivitas dan } \\
\text { kualitas iklim } \\
\text { investasi daerah } \\
\text { dalam upaya } \\
\text { mendukung } \\
\text { pertumbuhan } \\
\text { ekonomi di atas } \\
\text { rata-rata }\end{array}$ & $\begin{array}{l}\text { Meningkatnya } \\
\text { jumlah investasi } \\
\text { yang masuk baik } \\
\text { PMA maupun } \\
\text { PMDN yang dalam } \\
\text { pengelolaannya } \\
\text { dilakukan secara } \\
\text { bijak }\end{array}$ & \begin{tabular}{l}
\multicolumn{2}{l|}{ Peningkatan } \\
layanan investasi \\
yang kondusif \\
melalui koordinasi \\
dan monitoring bagi \\
setiap stakeholder \\
yang terlibat dalam \\
investasi daerah.
\end{tabular} & $\begin{array}{l}\text { Mendorong perbaikan } \\
\text { iklim investasi melalui } \\
\text { pemberian pencerahan } \\
\text { terhadap setiap rencana } \\
\text { kebijakan pada percepatan } \\
\text { pengembangan sektor riil } \\
\text { dan pemberdayaan usaha } \\
\text { mikro, kecil dan menengah } \\
\text { pada SKPD teknis lingkup } \\
\text { pemerintah kabupaten }\end{array}$ \\
\hline
\end{tabular}

Sumber : Kantor Bapada dan PM Kabupaten Buton, 2013

Proses perumusan kebijakan perencanaan pada Bappeda dan Penanaman Modal Kabupaten Buton telah dituangkan dalam Kebijakan Umum APBD yang merupakan sasaran dan kebijakan daerah dalam satu tahun anggaran yang menjadi petunjuk dan ketentuan umum yang disepakati oleh Pemerintah Daerah dan DPRD sebagai pedoman dalam Penyusunan Rancangan Anggaran Pendapatan dan Belanja Daerah. Oleh karena itu, penyusunan Kebijakan Umum APBD Kabupaten Buton Tahun Anggaran 2013 diarahkan untuk:

(1) Mewujudkan agenda Rencana Pembangunan Jangka menengah Daerah Kabupaten Buton tahun 2013-2017, yang merupakan penjabara visi, misi dan program kepala Daerah Kabupaten Buton periode 2012-2017 dengan tetap memperhatikan RKPD Propinsi Sulawesi Tenggara Tahun 2013 dan RKP 2013;

(2) Mewujudkan agenda pembangunan daerah dalam Rencana Kerja Pemerintah Daerah (RKPD) Kabupaten Buton tahun 2013 yang meliputi 5 (lima) isu strategis dan ditindaklanjuti dengan program dan kegiatan-kegiatan.

Berkenan dengan hal tersebut diatas, agar alokasi anggaran pada program dan kegiatan SKPD lebih realistis, terukur serta akuntabel perlu disusun kebijakan pendapatan, belanja dan pembiayaan daerah sebagai pedoman dalam penyusunan APBD Kabupaten Buton Tahun Anggaran 2013. Berikut hasil wawancara penulis dengan Kepala Bagian Pembangunan Sekretariat Daerah Kabupaten Buton Bapak La Kabona, S.Sos menyatakan:

“...Dalam era otonomi daerah seperti yang sudah berjalan lebih dari 10 tahun seperti sekarang ini, daerah diberi kewenangan yang lebih besar untuk mengatur dan mengurus rumah tangganya sendiri. Tujuannya antara lain adalah untuk lebih mendekatkan pelayanan pemerintah kepada masyarakat, memudahkan masyarakat untuk memantau dan mengontrol penggunaan dana yang bersumber dari Anggaran Pendapatan dan Belanja Daerah (APBD), Pemerintah Daerah Kabupaten Buton dalam proses 
kebijakan sering melibatkan steakholder karena tanpa mereka formulasi kebijakan tidak sesuai dengan apa yang dibutuhkan masyarakat". (Hasil wawancara tanggal 3 September 2013).

Selanjutnya wawancara penulis dengan Bapak Kaimuddin, S.Sos (Kasubid Promosi Investasi) menyatakan :

"...Perencanaan pembangunan di
Kabupaten Buton mampu
menangkap kebutuhan masyarakat
dalam mengembangkan potensi
daerah dan mampu mengantisipasi
perkembangan dinamika
masyarakat yang melibatkan
seluruh stakeholder dalam
perencanaan pembangunan
daerah. Sehingga kebijakan dalam
perencanaan dapat meningkatkan
kemampuan investasi daerah
dalam penyelenggaraan aktifitas
ekonominya di Kabupaten Buton
yang makin produktif dan makin
mandiri". (Hasil wawancara
tanggal 4 September 2013).

Tujuan merupakan penjabaran atau implementasi dari pernyataan misi dan tujuan sebagai hasil akhir yang akan dicapai atau dihasilkan dalam jangka waktu 5 (lima) tahun. Tujuan ditetapkan dengan mengacu kepada pernyataan visi dan misi sehingga rumusannya harus dapat menunjukkan suatu kondisi yang ingin dicapai di masa mendatang. Untuk itu tujuan disusun guna memperjelas pencapaian sasaran yang ingin diraih dari masing-masing misi.

\section{Proses Formulasi Kebijakan Perencanaan Pada Bappeda Dan Penanaman Modal Kabupaten Buton}

Aspek perencanaan memiliki peranan penting dalam membina serta mengembangkan otonomi daerah, karena melalui perencanaan, jauh sebelum terjadi perwujudan pembangunan, masyarakat lebih banyak mengerti tentang situasi daerahnya dan peranannya untuk berpartisipasi. Perencanaan akan menjadi katalisator pembangunan daerah yang didukung oleh masyarakat setempat, masyarakat memahami tentang kebijakan pemerintah dan dapat memperhitungkan kemampuannya dalam mendukung pembangunan daerah atas dasar otonomi yang dimilikinya.

Berdasarkan hasil wawancara penulis dengan Kasubid Evaluasi dan Pelaporan Vivianti Nafii, S.Pi, menyatakan:

"...Perencanaan sebagai suatu kebijakan merupakan proses kegiatan usaha yang dilakukan secara terus menerus dan komprehensif serta memiliki tahapan yang sistematis terhadap serangkaian kegiatan-kegiatan yang sedikit banyak berhubungan beserta konsekuensi-konsekuensinya bagi mereka yang bersangkutan daripada sebagai keputusan tersendiri." (Hasil wawancara tanggal 4 September 2013).

Proses perumusan kebijakan yang sangat beragam ditandai dengan banyaknya studi menyangkut proses perumusan kebijakan yang megharuskan keikutsertaan (partisipasi) masyarakat, dengan kata lain bahwa proses itu tidak hanya dimonopoli oleh pemerintah (birokrat). Kebijakan publik sebagai suatu rangkaian kegiatan atau langkah tindakan, didalamnya terdapat proses yang divisualisasikan sebagai 
serangkaian tahap yang saling bergantung yang diatur menurut urutan waktu. Setiap tahap berhubungan dengan tahap berikutnya, dan tahap terakhir (penilaian kebijakan) dikaitkan dengan tahap pertama (penyusunan agenda) atau tahap ditengah dalam aktivitas yang tidak linear. Hal ini didasarkan pada hasil wawancara penulis dengan Kabid Statistik dan Evapor bapak Drs. L.M. Takdir, M.Si beliau menyatakan :

“...Pola penyelenggaraan pemerintahan yang baik (good governance) dalam era otonomi daerah yang dititik beratkan pada proses perumusan kebijakan yang demokratis dengan tujuan mempromosikan good governance pada tingkat pemerintah daerah, melalui partisipasi publik dalam proses pengambilan kebijakan. Sampai sekarang belum terungkap bagaimana peran para stakeholders dalam proses perumusan kebijakan publik di Kabupaten Buton, disamping faktor-faktor apa saja yang dapat berpengaruh terhadap sinergi para stakehoders dalam proses perumusan kebijakan pada Bappeda dan Penanaman Modal di kabupaten Buton". (Hasil wawancara tanggal 5 September 2013).

Perencanaan sebagai suatu kebijakan merupakan proses kegiatan usaha yang dilakukan secara terus menerus dan komprehensif serta memiliki tahapan yang sistematis, bahwa tahap-tahap dalam suatu proses perencanaan terdiri dari :

(1) Penyusunan rencana yang meliputi tinjauan keadaan, baik sebelum memulai suatu rencana (review before take off maupun tinjauan terhadap pelaksanaan rencana sebelumnya of performance), perkiraan keadaan masa yang akan dilalui rencana (forecasting), penetapan tujuan rencana (plan objectives) dan pemilihan cara-cara pencapaian tujuan rencana, identifikasi kebijakan atau kegiatan usaha yang perlu dilakukan dalam rencana serta pengambilan keputusan sebagai persetujuan atas suatu rencana.

(2) Penyusunan program rencana yang dilakukan melalui perumusan yang lebih terperinci mengenai tujuan atau sasaran dalam jangka waktu tertentu, suatu perincian jadwal kegiatan, jumlah dan jadwal pembiayaan serta penentuan lembaga atau kerja sama antar lembaga mana yang akan melakukan program-program pembangunan. Tahap ini seringkali perlu dibantu dengan penyusunan suatu tahap flow-chart, operationplan atau network-plan.

(3) Pelaksanaan rencana (implementasi) yang terdiri atas eksplorasi, konstruksi dan operasi. Dalam tahap ini, kebijakankebijakan perlu diikuti implikasi pelaksanaannya, bahkan secara terus menerus memerlukan penyesuaian-penyesuaian.

(4) Tahap selanjutnya adalah pengawasan atas pelaksanaan rencana yang bertujuan untuk mengusahakan supaya pelaksanaan rencana berjalan sesuai dengan rencana, apabila terdapat penyimpangan maka perlu diketahui seberapa jauh penyimpangan tersebut dan apa sebabnya serta dilakukannya 
tindakan korektif terhadap adanya penyimpangan. Untuk maksud tersebu, maka diperlukan sustu system monitoring dengan mengusahakan pelaporan dan feedback yang baik daripada pelaksana rencana.

(5) Evaluasi untuk membantu kegiatan pengawasan, yang dilakukan melalui suatu tinjauan yang berjalan secara terus menerus (concurrent review). Disamping itu, evaluasi juga dapat dilakukan sebagai pendukung tahap penyusunan rencana yakni evaluasi sebelum rencana dimulai dan evaluasi tentang pelaksanaan rencana sebelumnya. Dari hasil evaluasi ini dapat dilakukan perbaikan terhadap perencanaan selanjutnya atau penyesuaian yang diperlukan dalam (pelaksanaan) perencanaan itu sendiri.

Berdasarkan hasil wawancara dengan Ketua DPRD Kabupaten Buton Bapak L.M. Yamin Majid, B.Sc, menyatakan:

“...perencanaan berhubungan erat dengan perumusan kebijakan (policy formulation), suatu proses di mana masyarakat Kabupaten Buton bisa mengatur ekonominya, institusi dan sumber-sumber sosial dan politiknya tidak hanya dipergunakan untuk pembangunan, tetapi juga untuk menciptakan kohesi, integrasi, dan untuk kesejahteraan rakyat. Dengan demikian, bahwa kemampuan suatu daerah mencapai tujuan sangat tergantung pada kualitas tata kepemerintahan di mana pemerintah melakukan interaksi dengan sektor swasta dan

masyarakat". (Hasil wawancara tanggal 6 September 2013).

Dalam kerangka itulah, kerja institusi Bappeda dan PM Kabupaten Buton seyogianya diorientasikan dari model "pemanjaan publik" ke "pertanggungjawaban publik". Pandangan mengenai prasyaratprasyarat institusional bagi pemerintahan Kabupaten Buton yang demokratis dalam mengekspresikan kepentingan publik, diantaranya adalah pandangan yang menyebutkan bahwa demokrasi pada dasarnya menunjuk pada hak berpartisipasi dalam mempengaruhi atau menentukan pembuatan keputusan, terutama yang menyangkut kepentingan individu anggota masyarakat, sementara itu partisipasi hanya dapat terjadi apabila terdapat proses pemberdayaan oleh suatu kekuatan politik yang memiliki hak, dalam hal ini pemerintah menginginkan dengan bijak jika seluruh rakyat tanpa kecuali, memiliki hak partisipasi sepenuhnya dalam pemerintahan. Berkaitan dengan hal ini, berikut ini ditampilkan hasil wawancara penulis dengan salah seorang Stakeholder yang menyangkut proses perumusan kebijakan perencanaan pada Bappeda dan PM Kabupaten Buton, menyatakan bahwa:

"...Tugas-tugas yang menyangkut
proses perumusan kebijakan
perencanaan dapat kami pahami,
dalam pelaksanaan tugas apabila kami
menemukan kesulitan dalam
penanganannya, hal itu kami
koordinasikan dengan rekan-rekan
sekerja atau langsung kepada
pimpinan, untuk mendapatkan solusi
pemecahannya." (Hasil wawancara
tanggal 6 September 2013).


Demikian juga apa yang dikemukakan oleh seorang Direktur LSM SINTESA Bapak Sukri Rauf, SE dalam wawancara dengan penulis menyatakan bahwa :

“...Tingkat pemahaman terhadap tugas-tugas yang tertera dalam uraian tugas cukup baik. Karena dalam pelaksanaanya proses perumusan kebijakan perencanaan telah diberi arahan atau penjelasan menyangkut mekanisme kebijakan perencaan dalam pelaksanaannya tidak mendapatkan kesulitan yang berarti" (Hasil wawancara tanggal 7 September 2013)

Berkaitan dengan kondisi diatas, hal ini menunjukkan bahwa proses perumusan kebijakan perencanaan Bappeda dan Penanaman Modal Kabupaten Buton cukup baik. Hal tersebut erat kaitannya dengan rasionalitas teknis, nilai, misi, tujuan organisasi serta fungsi Bappeda dan Penanaman Modal Kabupaten Buton sebagai unsur pelaksana yang membantu Bupati dalam menyelenggarakan tugas-tugas pemerintahan, administrasi, organisasi, dan tata laksana serta memberikan pelayanan administrasi kepada seluruh perangkat daerah Kabupaten.

Dalam konteks ini, proses demokrasi mengandung visi sistem politik hal mana para warganya memandang satu sama lain sederajat dalam kehidupan politik, secara bersama-sama berdaulat dan memiliki kapasitas sumber daya dan lembaga yang dibutuhkannya guna memerintah (govern) dari mereka sendiri. Sehingga kerangka teori yang terkait dengan penelitian tentang Sinergi Birokrasi,
Swasta Dan Masyarakat Dalam Proses Formulasi Kebijakan Perencanaan Pada Bappeda Dan Penanaman Modal Kabupaten Buton sangat bermanfaat untuk memahami lebih jauh tentang implementasi good governance dalam era otonomi daerah, dengan titik berat pada proses perumusan kebijakan yang demokratis.

\section{KESIMPULAN DAN SARAN}

\section{Kesimpulan}

Berdasarkan uraian pada bab IV analisis dan interpretasi data, dapat diambil beberapa kesimpulan sebagai berikut :

Dalam Proses formulasi kebijakan perencanaan pada Badan Perencanaan Pembangunan Daerah dan Penanaman Modal Kabupaten Buton dan Sinergi para stakeholders (Birokrasi, Pihak Swasta dan Masyarakat) dalam peningkatan kualitas Sumber Daya Manusia (SDM) perencana, telah dilaksanakan pelatihan perencanaan partisipatif bagi perangkat kecamatan, pelatihan aparat perencana bagi aparatur perencana SKPD se Kabupaten Buton. Selain itu, untuk meningkatkan kualitas SDM aparatur Bappeda dan PM, juga telah diikutsertakan dalam beberapa Pendidikan dan Pelatihan (Diklat) maupun Bimbingan Teknis (Bimtek). Peningkatan kualitas koordinasi perencanaan, monitoring dan evaluasi melalui kerjasama dengan Stakeholder. Pelaksanaan Program Kegiatan perencanaan yang dilakukan oleh Badan Perencanaan Pembangunan Daerah dan Penanaman Modal Kabupaten Buton, selama ini telah mewujudkan adanya capaian hasil-hasil pembangunan yang cukup mengembirakan, Kebijakan Badan 
Perencanaan Pembangunan Daerah dan Penanaman Modal tahun 2013 sesuai dengan tugas pokok dan fungsi serta kewenangan yang dimiliki, dengan mempertimbangkan kondisi dan kemampuan keuangan daerah, agar Perencanaan Pembangunan yang dilaksanakan dapat Sinergis, Akurat dan Akuntabel sesuai dengan kebutuhan masyarakat dan daerah, serta sistem Koordinasi dapat berjalan sesuai dengan peraturan yang berlaku dan pelaksanaan pengendalian serta evaluasi sesuai dengan harapan.

\subsection{Saran}

Berdasarkan hasil interpretasi data dan kesimpulan diatas, maka penulis mencoba merekomendasikan beberapa hal dalam rangka Sinergi Birokrasi, Swasta Dan Masyarakat Dalam Proses Formulasi Kebijakan Perencanaan Pada Bappeda Dan Penanaman Modal Kabupaten Buton, yaitu :

Melalui penelitian ini, diharapkan akan didapat konsep dan teori baru khususnya menyangkut sinergi birokrasi, sektor swasta dan masyarakat dalam proses formulasi kebijakan perencanaan sebagai upaya menciptakan good governance dalam era otonomi daerah dengan mengevaluasi keluhan-keluhan serta mencari solusi untuk memperbaiki sinergitas dengan melibatkan Pemerintah Kabupaten Buton dengan pihak swasta dan masyarakat. Meningkatan peran dan kapasitas seluruh SKPD termasuk Bappeda dan PM Kabupaten Buton yang diberi tugas dalam perencanaan pembangunan daerah untuk mengatasi permasalahan dan tantangan dalam pengambilan kebijakan. Peran Bappeda dan PM sangat strategis karena perencanaan merupakan pijakan awal untuk menentukan arah pembangunan daerah dengan mengoptimalkan sumber daya dan melibatkan para pelaku pembangunan/stakeholder. 


\section{DAFTAR PUSTAKA}

Abdul Wahab, Solichin, 2001, Analisis Kebijaksanaan : Dari Formulasi Ke ImplementasiKebijaksanaan Negara, Bumi Aksara, Jakarta.

Agus Dwiyanto, 2004, Manajemen Untuk Pembangunan Negara Berkembang, LP3ES, Jakarta.

Alavi, Hamza, The State in Post-Colonial Societies :Pakistan and Banglades, New Left Review, No. 74, JuliAgustus 1972.

Ancok, Djamaludin, 2007, Teknik Penyusunan Skala Pengukur, Pusat Penelitian Kependudukan UGM, Yogyakarta

Arikunto, Suharsimi, 2006, Prosedur Penelitian Suatu Pendekatan Praktek, Rineka Cipta, Jakarta.

Arsyad, Lincolin, 2009, Ekonomi

Pembangunan, Edisi Ketiga, YKPN Yogyakarta

Barkley, George E., 1978, The Craft of Public Administration, Allin and Bacon, Inc.

Djiwandono, Soedjati, 2004, Kekuatan dan Keterbatasan Pendekatan yang Berpusat pada Negara (State Centered)", Jurnal Ilmu Politik Nomor 6.

Dunn, William, N, 1999, Pengantar Analisis Kebijakan Publik, Gadjah Mada University Press, Yogyakarta.

Dye, Thomas R., 1992, Understanding Public Policy (Seventh Edition), Prentice Hall, Englewood Cliffs, New Jersey 07632.

Fatah, Eef Saefullah, 2001, Memberdayakan Islam dalam Politik, dalam Buku Otonomi Daerah Perspektif Teoritis dan Praktis, BIGRAF Publishing bekerjasama UMM, Yogyakarta.

Gafar, Affan, (2000), Politik Indonesia Transisi Menuju Demokrasi, Yogyakarta, Pustaka Pelajar

Giddens, Anthony, 1990, The Consequences of Modernity,
Stanford, California : Stanford University Press.

Keban, Yeremias T., 2000, Good Governance dan Capacity Building sebagai Indikator Utama dan Fokus Penilaian Kinerja Pemerintahan, dalam JurnalPerencanaan Pembangunan, Jakarta.

Huntington, Samuel P., 1991, The Third Wave, Democratization in the Late Twentieth Century, Oklahoma University Press, Norman, Oklahoma.

Lembaga Administrasi Negara, 2000, Akuntabilitas dan Good Governance, Modul Sosialisasi Sistem Akuntabilitas Kinerja Instansi Pemerintah (AKIP), Jakarta.

Maskun, Sumitro, 2001, Aspek Perencanaan Dalam Otonomi Daerah, dalam Buku Otonomi Daerah Peluang dan Tantangan, Pustaka Sinar Harapan, Jakarta.

Mc. Gregor, 1966, Ledership and Motivation, MIT Press, Cambridge, Mass.

Moleong, Lexy J., 2005, Metodologi Penelitian Kualitatif, Remaja Karya, Bandung.

Pamudji, Sapari, 1984, Pelaksanaan Azas Desentralisasi dan Otonomi Daerah di Dalam Sistem Administrasi Negara Kesatuan Republik Indonesia, Pidato Pengukuhan Sebagai Guru Besar Tetap Dalam Ilmu Administrasi Negara pada Institut Ilmu Pemerintahan, Departemen Dalam Negeri, Di Jakarta 15 Februari 1984.

Pide, Andi Mustari, 1997, Otonomi Daerah dan Kepala Daerah Memasuki Abad XXI, Gaya Media Pratama, Jakarta.

Rahardjo, M. Dawam, 1984, Transformation of The State in the Context of Transnationalization, 
Prisma, The Indonesian Indicator.

Rasyid, Ryaas, 2007, Makna Pemerintahan : Tinjauan dari segi Etika dan Kepemimpinan, P.T. Yarsif Watampone, Jakarta.

Redjo, Samugyo Ibnu, 2001, Reposisi Birokrasi dalam Pelaksanaan Otonomi Daerah: Demokrasi dan Model, dalam Buku Otonomi Daerah Perspektif Teoritis dan Praktis, BIGRAF Publishing bekerjasama UMM, Yogyakarta.

Rondinelli, 2003, Development Projects As Policy Experiment : An Adaptive Approach to Development Administration, Mathuen, London.

Said, M. Mas'ud, 2001, Konstruksi Negara Demokrasi : Implementasi Keadilan dan Kesejahteraan Bersama sebagai Usaha Demokratisasi, dalam Buku Otonomi Daerah Perspektif Teoritis dan Praktis, BIGRAF Publishing bekerjasama UMM, Yogyakarta.

Santoso, 2003, Teori Birokrasi dan Globalisasi. Yogyakarta: Insist Press, 2001

Singarimbun, Masri dan Effendi Sofian, 2007, Metode Penelitian Survay, Edisi Revisi, LP3ES, Jakarta.

Sosialismanto, Duto, 2001, Hegemoni Negara, Ekonomi Politik Pedesaan, Lapera Pustaka Utama, Yogyakarta.

Sugiyono, 2001, Metode Penelitian Administrasi, Alfabeta, Bandung.

Surakhmad, Winarno, 2005, Dasar dan Teknik Research, CV. Tarsito, Bandung
Suseno, Frans Magnis, 2008, Etika Politik, Prinsip-prinsip Moral Dasar dan Kenegaraan Modern, Gramedia, Jakarta.

Tjokroamidjojo, Bintoro, 2007, Pengantar Administrasi Pembanguan, LP3ES, Jakarta.

Tjokroamidjojo, Bintoro, 2003, Perencanaan Pembangunan, Gunung Agung, Jakarta.

Thoha, Miftah, 2000, Peranan Administrasi Publik dalam Mewujudkan Tata Kepemerintahan yang Baik, Disampaikan pada Pembukaan Kuliah Program Pasca Sarjana, UGM, Yogyakarta.

Usman, Husaini dan Purnomo Setiady Akbar, 2001, Metodologi Penelitian Sosial, Bumi Aksara, Jakarta

Utomo, Warsito, 2007, Sesi-sesi Kuliah Reformasi Administrasi, Magister Administrasi Publik UGM, Yogyakarta

Widodo, Joko, 2001, Good Governance : Telaah dari Dimensi Akuntabilitas dan Kontrol Birokrasi pada Era Desentralisasi dan Otonomi Daerah, Insan Cendekia, Surabaya.

Winarno, Budi, 2009, Teori Kebijaksanaan Publik, Pusat Antar Universitas- Studi Sosial UGM, Yogyakarta.

Republik Indonesia, 2004, "UndangUndang Nomor 32 Tahun 2004 Tentang Pemerintahan Daerah", Jakarta. 